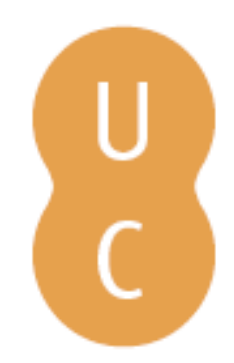

\title{
pommalina
}

\section{Edward Said, V. S. Naipaul and the condition of the exile}

Autor(es): Matos, Jacinta Maria

Publicado por: Imprensa da Universidade de Coimbra

URL

persistente:

URI:http://hdl.handle.net/10316.2/42321

DOI:

DOI:https://doi.org./10.14195/978-989-26-1308-6_11

Accessed : $\quad$ 26-Apr-2023 15:33:32

A navegação consulta e descarregamento dos títulos inseridos nas Bibliotecas Digitais UC Digitalis, UC Pombalina e UC Impactum, pressupõem a aceitação plena e sem reservas dos Termos e Condições de Uso destas Bibliotecas Digitais, disponíveis em https://digitalis.uc.pt/pt-pt/termos.

Conforme exposto nos referidos Termos e Condições de Uso, o descarregamento de títulos de acesso restrito requer uma licença válida de autorização devendo o utilizador aceder ao(s) documento(s) a partir de um endereço de IP da instituição detentora da supramencionada licença.

Ao utilizador é apenas permitido o descarregamento para uso pessoal, pelo que o emprego do(s) título(s) descarregado(s) para outro fim, designadamente comercial, carece de autorização do respetivo autor ou editor da obra.

Na medida em que todas as obras da UC Digitalis se encontram protegidas pelo Código do Direito de Autor e Direitos Conexos e demais legislação aplicável, toda a cópia, parcial ou total, deste documento, nos casos em que é legalmente admitida, deverá conter ou fazer-se acompanhar por este aviso.

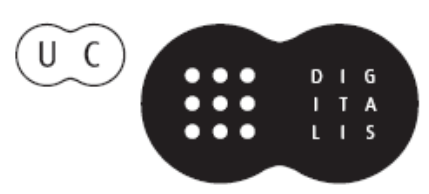





\section{E D W A R D SAID, V. S. NAIPA UL AND THE CONDITION OF THE EXILE}

Jacinta Maria Matos

Resumo: $O$ artigo centra-se na hostilidade mútua entre duas figuras de grande relevância para os Estudos Pós-coloniais Edward Said e V. S. Naipaul - e nas perspetivas opostas que cada uma propõe sobre a condição do exílio. Interrogando-se sobre as razões dessa bem documentada hostilidade, o estudo investiga os pontos em comum entre as duas figuras, em termos de origem, antecedentes familiares e educação, traçando as respetivas trajetórias de vida para explicar como cada uma chegou a uma posição muito própria sobre o papel do intelectual no mundo pós-colonial.

Palavras-chave: Edward Said; V. S. Naipaul; exílio; Estudos Pós-coloniais.

Abstract: The essay focuses on the mutual hostility between two central figures in the field of Postcolonial Studies - Edward Said and V.S. Naipaul - and on their opposing perspectives on the condition of the exile. Interrogating the possible reasons for their well-documented hatred of each other, the essay investigates what they have in common in terms of origin, 
background and education, and traces their trajectories to try and explain why each arrived at his particular position on the role of the intellectual in a postcolonial world.

Keywords: Edward Said; V. S. Naipaul; exile; Postcolonial Studies.

Allow me to start with a short piece of autobiography: when, in the mid- to late eighties, I was starting to write my $\mathrm{PhD}$ thesis on contemporary English travel writing (under Maria Irene's inspiring supervision), I inevitably came across V. S. Naipaul. His books on India and the Arab countries fascinated me, because they seemed to come from somebody who was working at the same time inside and outside the long and distinguished tradition of English travel writing about the Orient. They spoke both with a voice that I could easily recognize, the voice of the arrogant, prejudiced, supercilious upper-class Englishman (or, to use the correct critical term, the voice of the colonizer), and with the voice of the (ex-)colonized, who was now appropriating and redirecting that tradition to make it speak of the deterritorialized, decentred condition of the emigrant and the exile, a figure cast afloat in a postcolonial world of uncertain choices, complex allegiances and split identities.

Just as inevitably, I came across Edward Said's seminal book Orientalism (and then his other ground-breaking work in the field of postcolonial studies), and was equally excited by the discovery of a theoretical framework which could help me understand more fully and give a new significance to the genre I was proposing to study and analyse.

The two figures came productively together in my research around travel writing, but they also became inextricably linked 
in other, more unexpected and uncomfortable ways: when I read Said's essay, "Intellectuals in the Post-colonial World" (published in Salmagundi, 1986), I found, to my surprise and dismay, that the critic I had learned to respect and admire had a very different view about an author who I was quickly coming to regard as one of the most interesting and enlightening voices on the postcolonial condition, that very same condition that Said was both a conscious representative of and a lucid, clear-sighted commentator on.

In that essay, where Said tries to find a new place and an alternative stance for Third World intellectuals in the highly volatile world of post- or neo-colonialism, Naipaul is portrayed as an example of those "rare - luckily. . . extremely rare - Third World intellectuals who manfully ascribed most of their present barbarities, tyrannies, and degradations to their own innately native histories, histories that were pretty bad before colonialism and that have reverted to that state after colonialism" (1986: 47). When, later in the essay, he comes to speak in more detail about Naipaul's work (in particular about the Indian and Islamic journeys that I had just read and was pondering on), his comments are even more devastating:

The most attractive and immoral move, however, has been Naipaul's, who has allowed himself quite consciously to be turned into a witness for the Western prosecution. There are others like him who specialize in the thesis of what one of them has called self-inflicted wounds, which is to say that we "non-Whites" are the cause of all our problems, not the overly maligned imperialists. (idem 53)

As for the actual report about life in India and the Arab countries that Naipaul's travel books provide, Said deems it "ignorant, illiterate and cliché-ridden," "full of the cheapest and the easiest of colonial mythologies about wogs and darkies, myths that even Lord Cromer 
and Foster's Turtons and Burtons would have been embarrassed to trade in outside their private clubs" (ibidem).

Could Said have been talking about the same books that I had read? Was it possible that I had got Naipaul completely wrong, and that such an authoritative critic as Said was right? Was Naipaul a traitor to the cause of the newly-emerging nations, were his insights into the condition of an independent, postcolonial India or Indonesia valueless? Did he unquestioningly side with the centre, rejecting his origins and identity as a member of that forgotten periphery that had been silenced by colonial discourse?

I battled with these questions (one idol being toppled by another), but what bothered me in particular about passages like the ones I quoted above was their extremely aggressive, violent - even virulent - tone, and the sneaking suspicion that somehow Said had lost the fair and unbiased perspective we expect of theoretical discourse, and had allowed a personal dislike, a subjective (do I dare say the word?) prejudice to intervene and cloud his judgment of Naipaul.

A few decades later I am still troubled by the issue, and fear that I cannot give (I might as well admit it from the outset), a satisfactory answer to this question. In my PhD thesis (again to be frank to the reader) I skirted the problem by referring to Said's scathing views on Naipaul as typical of the by then pervasive critical opinion that regarded Naipaul as a thorn in the flesh of postcolonial studies, an uncomfortable, politically incorrect figure who refused to subscribe to a positive strategy of empowerment for Third World countries. Such critical views clearly had no time for less celebratory, darker visions of the newly-acquired condition of independence and of the search for a new identity that it entailed. Was I unfair to Said?

I also argued that Naipaul was a complex, many-sided figure, who did speak with the recognizable voice of the centre, but in so doing was setting himself up as a paradigm of the mimicry that the colonial system demanded of its subjects, thereby exposing 
the internal contradictions, tensions and ruptures of imperial discourses and practices. I have since, in my continued interest in Naipaul, extended this argument, and come to regard his writing as deliberately occupying that space of interdiction which must never be crossed by either colonizer or colonized so as to perpetuate the difference between them, that "area of darkness" which Imperial education intended should be left vacant, unoccupied, a buffer zone between the colonizer and the colonized (cf. Matos 2003: 184) that was meant to guarantee the authority of the one over the other.

I did not deny that much in Naipaul is objectionable, shocking, sometimes even revolting, but it seemed to me then (it still seems to me now) that he was, with unusual and commendable honesty and frankness, admitting to a part of himself that he could not ignore and that he deliberately sets himself up for our contemplation and instruction as a by-product of colonialism. And then, of course, there were Naipaul's other personae that teach us about the loss of a pristine identity and of a secure frame of reference, of a confusion and anxiety which spoke - with equal honesty and frankness - of the postcolonial's impossible quest for simple and single origins, beginnings and self-definitions. Was I over-generous to Naipaul?

But none of this is a satisfactory way to address a question that has been at the back of my mind since then, and that I would like to explore more fully in this essay. Why is Said so harsh (possibly even unfair) in his criticism of Naipaul? Why is it that he cannot read, in Naipaul, all that I think is there? Why is Said so persistent and consistent in using derogatory and insulting epithets about Naipaul, variously calling him a "scavenger" "in the ruins and derelictions of postcolonial history" (2000: 100), "a belated Kipling" (idem: 115) and a shameless "postcolonial renegade" (1985: 98)?

I am not sure, as I said before, that I can answer that question fully and leave the reader with the comfort of a well thought-out, well-argued, fully convincing explanation. But what I can do - and 
will try and offer for discussion and possibly for revision - is to give an account of how I have come to deal with these issues, a process which turned (not surprisingly) into an investigation of how these two figures look at their own situation in the world and give meaning to their common condition as exiles.

In so doing my primary objective is not to exculpate either for what in both appears to me to be wrong, incorrect, reductive, false or unfair. Rather than pass cursory judgment on Said and Naipaul, I would rather adopt the more positive stance of trying to understand why each arrived at their respective positions on postcolonial issues, an inquiry which, I hope, will prove rather more interesting and productive.

The starting-point of this inquiry was obvious, and begins with something that always struck me as strange and puzzling: despite their different origins, nationalities and life-stories, Said and Naipaul have so much in common, in terms of background, education, their experience of the diaspora, and eventually their status as writers and intellectuals (recognized not only in the West but in the whole world), that you would expect that these similarities would somehow give the first a good understanding of (if not actually an immediate sympathy for) the second. This, however, is very clearly not the case.

Let me start by briefly enumerating the similarities between the two figures: they were both born in the mid-1930s, in countries which were under British rule or influence (Naipaul in Trinidad, Said in Palestine), thus having a common experience of life under British colonialism. They were both educated in British schools of a type that was common throughout the empire, places where, in Said's words, local students "were all treated as if [they] should (or really wanted to) be English" (2000: 39; italics in the original) institutions that, according to Naipaul, demanded "a blind, driven kind of colonial studying" (idem: 9). In short, schools that were 
intended to form colonial elites by encouraging the mimicry of the centre, while providing an idealized, unreachable model of what Englishness is and should be. (Macaulay still cast a long, dark shadow over an Empire where the sun never set).

They both belonged to minority groups, communities that were isolated - insulated - from the rest of society (Naipaul was part of the Indian community, one of many in the multi-ethnic society of the West Indies; Said's family were Palestinian Christians living in Egypt). They both speak of going to school as their first experience of displacement, of not fitting in, and of the growing awareness of a difference that neither could, at the time, fully explain or rationalize, but which created them as "outsiders" in an unfriendly, strange world. This feeling of loneliness and separateness was increased by exposure to a culture that they could not relate to, a foreign world of "meadows, castles and Kings John" (Said 2000: 39) or of "fairy tale[s]", "far off and dateless" (Naipaul 6), a literature that spoke of a place which "was two worlds away" (idem 10) from their private lives and the reality around them.

But books and reading provided both with an escape to a life of the mind that helped them overcome their condition as oddities and misfits: Naipaul developed, from age 11, the dream of being a writer, "a private idea, and a curiously ennobling one, separate from school and separate from the disordered and disintegrating life of our Hindu extended family" (5); Said, in his own words, "developed the habit of mentally extending the story presented in a book, pushing the limits to include [himself]; gradually [he] realized that [he] could become the author of [his] own pleasures, particularly those that took [him] as far away as possible from the choking impingements of family and school" (2000: 33).

Books, literature - echoes of another, distant world, that became for both, as children, objects of fascination but also of anxiety, an exhilarating world of the imagination where you could reconstruct 
yourself as hero, but which also kept you at arm's length, forever reminding you that you "were not quite right" (Said 2000: 19) and that you could never feel at ease in this world because "too many questions got in the way" (Naipaul 10) of understanding and belonging.

Both Naipaul and Said later travelled to this distant world of the centre, the centre of culture and power far removed from the peripheries where they were born. They went there to pursue their studies in prestigious institutions and recognized centres of academic excellence - Naipaul to Oxford, with a scholarship from the British government, Said to a private school in the U.S., and then on to Princeton and Harvard. Neither returned to their place of origin for more than brief periods of time, having settled (if settled is the right word. . .) respectively in England and the U.S. for the rest of their lives.

Another experience of up-rootedness and displacement, another chance to belong that seems to have evaded both of them. As a West Indian in England and as a Palestinian and Arab in the U.S., Naipaul and Said remained irrevocably Others in the societies they now lived in and never ceased to feel "out of place" in the West. But going back had ceased to be an option: they were also at this point incapable of returning home and picking up life where they had left off. By this time, they both had become, technically speaking, exiles.

A close study of their biographies also reveals the amazing similarities in the ways they devised to minimize or overcome the painful absence of a familiar reality: they both created a base (I prefer to call it a base rather than a home), a secure and fixed point of reference amidst the instability and flux of lives led between two cultures and identities: Naipaul has lived in a cottage in Wiltshire (in the most idyllic part of the English countryside) since 1970; Said started and ended his academic career in Columbia, having lived in 
New York for over 30 years. From this base, however, they struck out in all directions, travelling all over the world on professional assignments or private visits, with a restlessness that borders on the obsessive, and which I believe ultimately dramatizes their unending search for meaningful origins and destinations, clear-cut points of departure and arrival.

And it is precisely here - in their respective quests for a home and an identity - that they part company and go their different ways, never to meet again. Naipaul went first back to Trinidad in an attempt to regain the "security" (the word is his) of the colonial world that he had left behind. It didn't work. The Trinidad he encountered was not the pure and pristine place of origin he had imagined, but a colonial creation, a world of "mimic men", trying to escape the margin by parodying the centre. A centre which, by this time, had been transferred from the British to the Americans, leaving Naipaul, like all ex-colonials, without the old reference point against which to define themselves.

He tried again, further afield, in the long-lost world of family origins, in India. But in India Naipaul again encounters a postcolonial world, an independent country that has moved on from the India of his ancestors, that timeless place of the emigrant's imagination which no longer exists among the chaotic, defiled, decayed India (again, the adjectives are his) that he describes in his Indian trilogy. What he does find in India is that his condition is irredeemably that of the Other. He discovers (and I am here paraphrasing him) that he is neither English nor Indian, that he is denied the victories of both. And he is ultimately regarded by both as inescapably alien.

Ultimately Naipaul came to recognize his quest for what it really is - an impossible dream. And this recognition provides the context for his other travel narratives, namely the books he wrote about the Arab countries, where he goes to confront the same issues he dealt with in his earlier narratives: the effects of what he sees as imperial 
systems of cultural, if not literal, occupation and colonization. What he seeks there and what he therefore necessarily finds, are people, like him, who are radically split within themselves and alienated from the rest of society, by-products of a colonial domination which, when it ended, did not immediately and unproblematically bring to the ex-colonial a single, pure, pristine identity with which he/ she could live.

On the basis of his subsequent work on Africa and the Arab countries, Naipaul's vision is and probably will remain a fractured one, made up of pieces that never quite come together as a whole, broken fragments that belong to different, even opposed worlds, out of which he cannot create a meaningful synthesis. He feels he has no home to go back to, and the only place he claims to belong to is the world of Literature. As Homi Bhabha has put it, he works to preserve an ideal of civility by transforming "the despair of postcolonial history into an appeal for the autonomy of art" (107). The void is still there, but just about made bearable in the rarefied regions of this idealized country - Literature with a capital L - which he chose to inhabit.

And what about Edward Said, a man who once said that the only place he really feels at home in is on an airplane and is credited with the invention of "travelling" theory, attempting to go back to the Jerusalem where he was born, and finding it under Israeli occupation? Or visiting Lebanon, where the family's holiday home had been literally destroyed during the civil war? Or returning to Egypt, where the cosmopolitan expatriate community he was part of had been disbanded after the Egyptian revolution and the emergence of Nasser and Arab nationalism? In a way, Said's homelessness is much more radical and profound than Naipaul's, the course of History having been so much more punishing to the places he could have gone back to to retrieve a sense of origins and beginnings. But in other ways of course it is not. 
After 1967 and the Six-day War, Said knew where he stood and where "home" was - or at least where it should be. He has referred to this historical and autobiographical moment as "the dislocation that subsumed all the other losses, the disappeared worlds of my youth and upbringing, the unpolitical years of my education, the assumption of disengaged teaching and scholarship at Columbia" (2000: 293; italics in the original). He phrases this experience in the language of rebirth, as the death of an old identity and the emergence of "the self beneath or obscured by 'Edward" (idem: 294), "Edward" the oddity, the misfit, the lost child and youth he had been until then. And it was clearly the commitment to a political cause that transformed him, giving direction and destination to the displacement and up-rootedness of his condition. He now had not so much a home to go back to as a home to look forward to, no matter how deferred in time its existence might be.

I would like to end by quoting a few passages from what, for me, is one of Said's most revealing - and for the purposes of this paper, more interesting - essays, "Reflections on Exile." I read it as exemplary of Said's capacity to engage with a political cause without erasing or smoothing down the complexities and ambiguities of his condition as an exile and of his many-sided identity as an academic, political commentator and activist, writer of newspaper articles and even musician. In this essay, he is still grappling with the difficulties of trying to make sense of what he himself terms "the unhealable rift forced between a human being and a native place" (173), a state whose "essential sadness can never be surmounted" (ibidem) and the achievements of which "are permanently undermined by the loss of something left forever" (ibidem). It is a daunting task, no less so because it seems, from the start, so self-defeating, a mere gloss over a "condition of terminal loss" (ibidem), a vain attempt to regain and reclaim, through the act of writing, all that cannot in your personal life ever be recovered. 
But the main reason why I would like to recall some of the ideas he expounds in that essay is that, when I re-read it with this paper in mind, so much of it seemed to me to speak directly about - and to - Naipaul himself, and to put into words, so much better than I ever could, an explanation of (although not an excuse for) some of those aspects of Naipaul's work that Said has elsewhere damned:

Exiles feel. . . an urgent need to reconstitute their broken lives, usually by choosing to see themselves as part of a triumphant ideology or a restored people. The crucial thing is that a state of exile free from this triumphant ideology - designed to reassemble an exile's broken history into a new whole - is virtually unbearable, and virtually impossible in today's world. (Said 2001: 177)

Thus Naipaul's dark vision and his unwillingness to subscribe to triumphant ideologies; thus Naipaul the "scavenger" who writes precisely about this unbearable state and from this impossible perspective where broken lives cannot be mended.

No matter how well they may do, exiles are always eccentrics who feel their difference (even as they frequently exploit it) as a kind of orphanhood.... Clutching difference like a weapon to be used with stiffened will, the exile jealously insists on his or her right to refuse to belong. (Said 2001: 182)

At this extreme the exile can make a fetish of exile, a practice that distances him or her from all connections and commitments. (idem: 183)

Thus Naipaul's refusal to commit himself to a cause - to any cause - or to speak on behalf of the Third World; thus Naipaul the "renegade". 
And finally, Said paraphrasing Adorno: "the only home truly available now, though fragile and vulnerable, is in writing" (idem: 184). Thus Naipaul's exclusive allegiance to a deterritorialized, nationless ideal of "Literature".

I seem to have come full circle and to have brought together again these two figures, after suggesting that, despite their common backgrounds, they went their separate ways and took divergent paths in the world of postcolonialism. But in no way is this intended to effect what would necessarily be an artificial and false reconciliation between the two. Writing may be the only abode available to the exile, but in the end there is writing and writing, and Naipaul's and Said's are of a very different kind. I prefer, therefore, to keep the two separate, and to accept that they are in many ways at war with each other, opposite if not actually irreconcilable figures trying to map out the confused geography of whole new territories of feeling and experience.

Or, if I may borrow Said's words from "Reflections on Exile" one last time, when he speaks of the "plurality of vision" of the exile, one of the few pleasures and privileges that the exile may claim because they productively give rise "to an awareness of simultaneous dimensions" (186), I choose to think of the two figures as Said does about his own condition, as "contrapuntal": separate but contiguous, fiercely independent but, despite themselves, somehow interconnected, both part of the chorus of postcolonial voices but each with his own, distinct and very audible, melodic line.

\section{Works cited}

Bhabha, Homi. The Location of Culture. London: Routledge, 1994. Print.

Matos, Jacinta Maria. "A educação (pós-)imperial de V. S. Naipaul”. Revista Crítica de Ciências Sociais 65 (2003): 175-185. Print.

Naipaul, V.S. Literary Occasions: Essays. London: Picador, 2003. Print. 
Said, Edward. "Orientalism Reconsidered." Culture Critique 1 (1985): 89-107. Print.

"Intellectuals in the Post-colonial World. Salmagundi 70/71 (1986): 44-64. Print.

Out of Place: A Memoir. London: Granta Books, 2000. Print.

- Reflections on Exile and Other Literary and Cultural Essays. London: Granta Books, 2001. Print. 